УДК 378.147:811.111

\title{
МОВНИЙ КОУЧИНГ ЯК ТЕХНОЛОГІЯ НАВЧАННЯ АНГЛІЙСЬКОЇ МОВИ ПРОФЕСІЙНОГО СПРЯМУВАННЯ У НЕЛІНГВІСТИЧНИХ $3 В О$
}

\author{
Щур Н. М. \\ natalya.schur@ukr.net \\ https://orcid.org/0000-0003-3119-6643 \\ Тернопільський національний технічний університет імені Івана Пулюя \\ Дата надходження 29.05.2020. Рекомендовано до друку 24.06.2020.
}

\begin{abstract}
Анотація. У статті розглянуто основні принципи коучингу та умови його ефективного проведення. Проаналізовано психофізіологічні механізми мовлення та підкреслено важливість їх урахування при проведенні мовного коучингу. Зазначено перспективи здійснення коучингового супроводу у вітчизняних нелінгвістичних 3ВО. Обгрунтовано триетапну модель мовного коучингу як методу навчання англійської мови професійного спрямування. Конкретизовано зміст етапів здійснення коучингового супроводу студентів / фахівців з метою розвитку їхньої іншомовної професійної компетентності.

Ключові слова: мовний коучинг, умови й етапи мовного коучингу, психофізіологічні механізми мовлення, мовленнєва діяльність, розвиток іншомовної професійної компетентності
\end{abstract}

Щур Н. М. Тернопольский национальный технический університет имени Ивана Пулюя Языковой коучинг как технология обучения английскому языку профессионального направления в нелингвистических вузов

Аннотация. В статье рассмотрены основные принципы коучинга и условия его эффективного проведения. Проанализированы психофизиологические механизмы речи и подчеркнута важность их учета при проведении языкового коучинга. Указаны перспективы осуществления коучингового сопровождения в отечественных нелингвистических вузах. Обоснована трехэтапная модель речевого коучинга как метода обучения английскому языку профессионального направления. Конкретизировано содержание этапов осуществления коучингового сопровождения студентов / специалистов с целью развития их иноязычной профессиональной компетентности.

Ключевые слова: языковой коучинг, условия и этапы речевого коучинга, психофизиологические механизмы речи, речевая деятельность, развитие иноязычной профессиональной компетентности

Shchur N. Ternopil Ivan Puluj National Technical University

Language coaching as a technology of teaching ESP in non-linguistic HEIs

Abstract. Introduction. The development of modern society causes the necessity of fluency in foreign languages, especially in English. This competence requires constant maintenance and development throughout life by means of the full immersion in a foreign language. One of the methods fostering language immersion is coaching. Purpose. To substantiate a three-stage model of language coaching as a method of teaching ESP in non-linguistic HEIs. Methods. Analysis of the psychophysiological mechanisms of speech perception / production and theoretical findings and practitioner's experience concerning the implementation of coaching in the higher education. Results. Language coaching is a three-stage process of assisting the individuals with the development of their professional foreign language competence. The main tool of language coaching is posing questions to encourage coaches to reflect on their language performance. The first stage of language coaching involves setting SMART goals for developing English skills, and creating and implementing an action plan for achieving these goals. The second stage includes putting the language skills developed during the first stage into practice, reflecting on the positive and negative aspects of the language performance and identifying areas that require further development. The third stage involves discussing the results of self-reflection with a coach and deciding on the ways of enhancing language skills and overcoming the obstacles coaches have encountered when speaking English. Conclusions. Language coaching as a method of teaching ESP is a three-stage process of developing professional foreign language 
competence incorporating preparation, communication and reflection. The substantial benefit of its implementation is engaging coaches into the lifelong process of improving their foreign language performance and enabling them to perform efficiently in the challenging situations.

Key words: language coaching, the stages of language coaching, the psychophysiological mechanisms of speech perception / production, language performance, the development of professional foreign language competence.

Постановка проблеми. Процеси економічної, політичної й соціокультурної глобалізації та інтернаціоналізація всіх сфер суспільного життя зумовлюють трактування володіння іноземними мовами, зокрема англійською, як одну із необхідних умов досягнення професійного успіху на сучасному висококонкурентному ринку праці. Це, в свою чергу, актуалізує пошук ефективних і результативних технологій вивчення іноземних мов, за допомогою яких студент зможе досягнути очікуваних результатів навчання, витративши мінімальну кількість часу і зусиль. Аналіз психофізіологічних особливостей мовлення доводить правильність думки, що мови неможливо навчити, мови можливо лише навчитись. Студенти потребують не автоматичного отримання готової інформації, а глибокого формування навичок і закріплення іншомовних мовленнєвих умінь (Коробко, 2009, с. 116). Фактично вивчення іноземної мови це неперервний процес розвитку іншомовної професійної компетентності (далі - ІПК), який вимагає від людини повного занурення в практику мовлення. Це твердження показує важливість використання особистісно-діяльнісного підходу до вивчення іноземних мов, одним із методів якого є коучинг.

Аналіз останніх досліджень і публікацій. Вивчення наукової літератури показує, що проблему використання технології коучингу в системі освіти досліджували чимало вітчизняних і зарубіжних науковців. Так, американські науковці A. Costa \& R. J. Garmston (2002) розробили концепцію когнітивного коучингу для професійного розвитку вчителів; J. Knight (2009) обгрунтував засади розроблення програм коучингового супроводу; P. Lord, M. Atkinson \& H. Mitchell (2008) проаналізували ефективність застосування коучингу в школах Англії та висвітлили основні труднощі й виклики, з якими стикаються педагоги; M. Rother (2011) запропонував методику постановки запитань у процесі коучингового супроводу; С. A. Toll (2005) розробив комплекс методичних вказівок щодо ефективного проведення коучингу з метою розвитку професійної компетентності вчителів.

У наукових розвідках С. А. Жицької та О. М. Ефімової (2017) висвітлено доцільність використання мовного коучингу та умови його ефективного застосування. D. Zeppos (2014) присвятив своє дослідження розробленню профайлу нейролінгвістичного коуча, а у праці R. M. Paling (2014) з'ясовано відмінності, які існують між традиційними методами навчання іноземних мов і мовним коучингом. Однак обгрунтування самого процесу здійснення коучингового супроводу студентів як методу навчання англійської мови у нелінгвістичних 3ВО 3 чітким виокремленням й аналізом його структурних складових не отримало належного дослідження.

Мета статті - на основі узагальнення науково-педагогічного досвіду проведення коучингу й аналізу психофізіологічних механізмів мовлення обгрунтувати триетапну модель мовного коучингу як технології навчання англійської мови професійного спрямування студентів нелінгвістичних ЗВО.

Основні результати дослідження. В основі науково-теоретичного обгрунтування коучингу лежить думка, що кожна людина володіє величезним резервом невикористаного прихованого потенціалу, а тому здатна змінюватись, розвиватись і вдосконалюватись (Costa \& Garmston, 2002). Проведений аналіз наукових джерел (Сфімова \& Жицька, 2017; Costa \& Garmston, 2002; Knight, 2007, 2009; Lord, Atkinson \& Mitchell, 2008; Rother, 2011; Toll, 2005) дає підстави стверджувати, що коучинг - це система сприяння людині у визначенні і досягненні їі особистих 
і професійних цілей за мінімальний час і з мінімальними зусиллями шляхом розкриття iї потенціалу та створення середовища, яке полегшує іiі рух до бажаної мети. Коучинг це не наставництво чи консультування, а технологія модифікації поведінки та мислення людини 3 метою розвитку вміння самостійно приймати правильні рішення, вирішувати проблеми, ефективно діяти у складних ситуаціях.

Основний інструмент коучингу - це постановка відкритих запитань, за допомогою яких коуч спрямовує людину у потрібному напрямку, підштовхує іiі до прийняття рішень, необхідних для досягнення бажаних результатів. Аналіз джерельної бази (Knight, 2007; Rother, 2011; Toll, 2005) засвідчує, що запитання відкритого типу активізують мислення, розвивають уміння здійснювати самоаналіз і самооцінювання на основі обсервування даних щодо власної діяльності, що сприяє прийняттю правильних рішень у складних ситуаціях.

Унаслідок опрацювання науково-педагогічної літератури (Costa \& Garmston, 2002; Knight, 2007; Lord, Atkinson \& Mitchell, 2008; Rother, 2011; Toll, 2005) ми виокремили умови ефективного проведення коучингу. Так, коучу необхідно:

- встановити довірливі й доброзичливі стосунки з людиною, уникати у спілкуванні осудливого тону;

- ставити запитання, які активізують мислення та спонукають до конкретизації, ретельного обдумування й удосконалення діяльності; наприклад, студенту можуть ставити такі запитання:

- 3 якою метою Ви здійснюєте розвиток ІПК (студенту потрібно вказати конкретну мету, наприклад, розвиток уміння вести ділову переписку або перемовини 3 міжнародними партнерами у сфері IT-бізнесу; виступати з презентаціями, які є інструментом продажу ідей, послуг і товарів в IT сфері; опрацьовувати велику за обсягом англомовну інформацію щодо ведення бухгалтерського обліку у США тощо);

- На якому етапі Ви перебуваєте зараз на шляху до досягнення мети?

- Які труднощі виникають у процесі досягнення мети? Що перешкоджає ії досягненню?

- Який Ваш наступний крок (етап) у досягненні Вашої мети? Що Ви від нього очікуєте?

- Коли Ви плануєте завершити цей етап і що свідчитиме про його завершення?

- здійснювати коучинг, дотримуючись послідовності його етапів, зокрема визначення рівня знань, окреслення цілей, побудова та реалізація стратегії їх досягнення;

- перефразовувати слова співрозмовника з метою їх уточнення або перевірки правильності розуміння;

- відводити час на обміркування відповіді;

- володіти методами збору аналітичних даних й об'єктивно їх висвітлювати.

На нашу думку, оскільки йдеться саме про мовний коучинг, то ще однією важливою умовою його здійснення $є$ врахування психофізіологічного механізму мовлення, який реалізується однаково і у рідній, і в іноземній мовах, та характеризується тьохрівневістю: мотиваційноспонукальний рівень, аналітико-синтетичний рівень, виконавчий рівень (Лозова, 2010, с. 23).

Розглянемо цей механізм детальніше. Аналіз наукових джерел (Виготський, 1999; Лозова, 2010) свідчить, що думка народжується не з іншої думки, а з мотивувальної сфери нашої свідомості, що охоплює наші потяги, потреби й інтереси. Відповідно, на першому мотиваційно-спонукальному - рівні взаємодія наших потреб, мотивів і мети створює ситуацію, що спонукає нас до мовленнєвої дії, яка несе в собі певну функцію, наприклад привітання, аргументування, наведення прикладів тощо (Лозова, 2010, с. 23-24). Суть другого - аналітикосинтетичного - рівня полягає в тому, що будь-яка думка людини є унікальною, тому не може бути прив'язана до якоїсь певної форми вираження. О.М. Лозова, посилаючись на Х. Джексона, стверджує, що “при продукуванні, або навпаки, сприйнятті мовлення має місце або відставання мовлення стосовно думки, або відставання думки стосовно мовлення” (Лозова, 2010, с. 21). Тож між думкою і мовленням спостерігається певна відстань у часі. Тобто, після того, 
як актуалізується думка, відбувається процес пошуку форми іï вираження. Після пошуку й добору засобів формування й оформлення думки реалізується третій - виконавчий - рівень, на якому відбувається процес продукування або рецепції висловлювання.

Важливу роль у мовленні відіграє механізм випереджувального відображення, який у рецепції висловлювання проявляється як імовірнісне прогнозування, а у продукуванні як випереджувальний синтез. Імовірнісне прогнозування - це процес висування мовцем найвірогідніших гіпотез з наступним їх підтвердженням або спростуванням у процесі рецепції (Зимняя, 1991; Коробко, 2009; Лозова, 2010). Випереджувальний синтез - це механізм, дія якого полягає у “створенні цілісного об’ єднання, в якому наступна ланка повинна бути попереджена випереджувальним імпульсом” (Коробко, 2009, с. 118). Реалізується цей механізм трьома лініями: 1) випередження лінією словесно-артикуляційної стереотипії (усередині слова); 2) випередження лінією слів; 3) випередження лінією тексту (Зимняя, 1991; Коробко, 2009; Лозова, 2010).

У площині нашого дослідження стрижневе значення має випередження лінією слів, яке проявляється в тому, що, промовляючи одне слово, мовець вже обумовлює випереджувальний синтез наступних слів. Конкретна актуалізація одного з можливих варіантів детермінується контекстом і ситуацією спілкування, внаслідок чого актуалізується найімовірніша для такої ситуації спілкування вербальна реалізація (Коробко, 2009,с. 188-119). Характеристика цієї лінії випереджувального синтезу показує, як важливо навчати не лише окремих слів іноземної мови, але й їх словосполучень у межах конкретного контексту й мовленнєвої ситуації (Лозова, 2010, с. 27).

Ураховуючи проаналізовані вище психофізіологічні механізми мовлення, ключового значення при здійсненні коучингу набувають експоненти функцій мовлення (functional exponents) та лексико-граматичні структури певної сфери (IT сфери, бізнес-сфери тощо), оскільки їх опрацювання з метою досягнення чітко визначених цілей (функцій) мовлення значно полегшує добір форм вираження думки і, відповідно, процес продукування чи рецепції висловлювання. Важливість опрацювання вказаних експонентів і структур доводить той факт, що “процес вибору форм вираження залежить, по-перше, від семантичних причин i, по-друге, від ступеня стійкості самих форм вираження. Ступінь стійкості визначається давністю становлення відповідної форми і частотністю її актуалізації” (Лозова, 2010, с. 21). Відповідно, для того, щоб оволодіти мовленнєвими навичками, окрім того, що потрібно володіти відповідним лексичним матеріалом і знати граматичні правила, що дають змогу “будувати” на їхній основі речення, необхідно всі ці знання якнайчастіше активізовувати, використовуючи їх у реальній мовленнєвій діяльності.

Отже, всі мовленнєві навички опрацьовуються та доводяться до автоматизму лише на практиці, коли мова $€$ постійно необхідним інструментом комунікації. Однак, стикаючись 3 мовленнєвою діяльністю у реальності, студенти стикаються із низкою проблем. Наприклад, вибір синтаксичної структури іноземною мовою часто пов'язаний з великими труднощами. Тому необхідна тривала навчальна робота з оволодіння різноманітними лексико-граматичними структурами виучуваної мови. Але досить часто тієї мовленнєвої практики, які студенти мають на занятті, навіть за умови використання викладачем комунікативного підходу, недостатньо. Коучинг як одна з технологій особистісно-діяльнісного підходу до вивчення іноземних мов сприятиме вирішенню цієї проблеми, оскільки, якщо мовець заздалегідь знає, в яку мовленнєву ситуацію він потрапить та які цілі (функції) його мовленнєвої діяльності, то, підготувавшись належним чином, він зможе значно легше спілкуватись іноземною мовою. Звичайно, зробити це самостійно без розуміння тонкощів психолінгвістики, когнітивістики, лінгводидактики й методики навчання іноземних мов для мовця досить складно і затратно за часом. Це зумовлює необхідність впровадження мовного коучингу як технології навчання англійської мови професійного спрямування в нелінгвістичних ЗВО. 
3 огляду на вищеописані психофізіологічні механізми мовленнєвої діяльності, на особливості здійснення коучингового супроводу та на специфікиу вітчизняної системи вищої освіти, виокремимо два основних варіанти впровадження мовного коучингу як технології навчання англійської мови професійного спрямування в нелінгвістичних ЗВО. По-перше, оскільки сьогодні багато студентів уже з 2-3-го курсу поєднують навчання з роботою за спеціальністю, виступають 3 доповідями на міжнародних студентських конференціях, беруть участь у міжнародних програмах обміну студентами та в програмах подвійних дипломів, де англійська мова $€$ необхідним інструментом комунікації, то коучинг доцільно проводити під час консультацій у форматі індивідуального супроводу студента в ході освітнього процесу. По-друге, оскільки розвиток ІПК - це неперервний процес, то другий варіант проведення коучингу передбачає супровід на платній основі фахівців IT сфери, бізнес-сфери тощо, яким потрібна іноземна мова в їхній професійній діяльності. Цілі розвитку ІПК за допомогою технології коучингу в обох випадках можуть модифікуватись на кшталт удосконалення таких умінь, як виступити з презентаціями, проходити співбесіду, брати участь у перемовинах / дискусіях, вести ділове листування, здійснювати бізнес-дзвінки тощо. На нашу думку, найефективніше здійснювати коучинговий супровід тих студентів чи фахівців, які принаймні володіють англійською мовою на рівні А2, відповідно до шкали, зазначеної у Загальноєвропейських Рекомендацій 3 мовної освіти.

Спираючись на виокремлені нами умови ефективного проведення коучингу й результати наших наукових розвідок щодо психофізіологічних особливостей мовленнєвої діяльності, коучинговий супровід студентів / фахівців з метою розвитку їхньої ІПК вважаємо за доцільне проводити у три етапи: 1) визначення цілей розвитку ІПК та підготовка до мовленнєвої діяльності; 2) здійснення мовленнєвої діяльності; 3) обговорення результатів мовленнєвої діяльності.

Ці етапи уможливлять залучення студентів / фахівців до неперервного циклу розвитку ІПК, який складається з чотирьох компонентів: 1) планування та підготовка до мовленнєвої діяльності; 2) здійснення мовленнєвої діяльності; 3) рефлексія мовленнєвої діяльності; 4) застосування результатів рефлексії з метою підвищення рівня ІПК (рис. 1). Ми розглядаємо рефлексію як комплексний процес розвитку ІПК, що охоплює аналіз, оцінювання й удосконалення мовленнєвої діяльності на основі практичного досвіду (Самохвалова, 2012; Шапар, 2005).

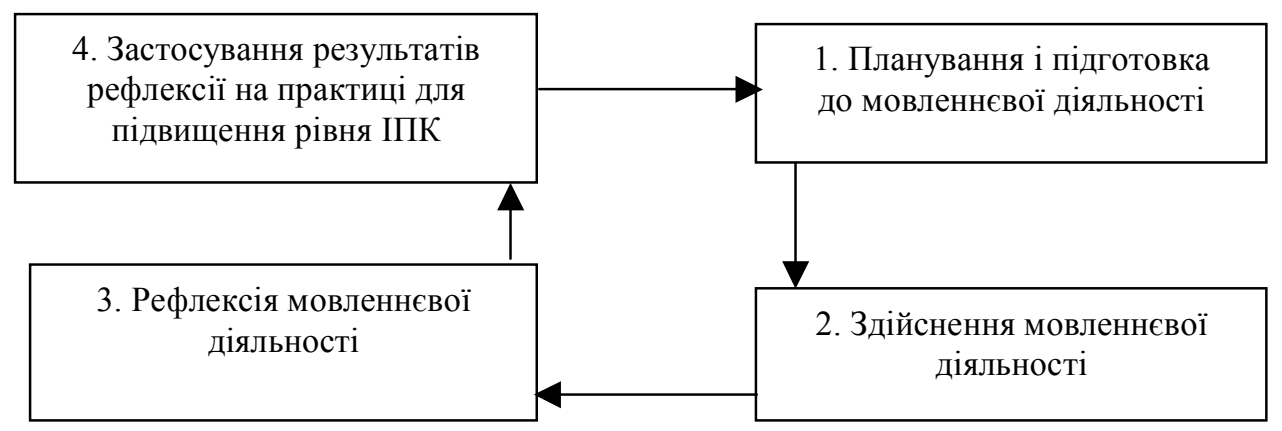

Рис. 1 Неперервний цикл розвитку ІПК

Розглянемо вищевказані етапи проведення мовного коучингу детальніше. Важливу роль відіграє перший етап - визначення цілей розвитку ІПК та підготовка до мовленнєвої діяльності, який проводиться у форматі аналізу навчальних потреб (needs analysis). На цьому етапі студент / фахівець за допомогою коуча, відштовхуючись від реальних комунікативних потреб, складає план підготовки до мовленнєвої діяльності із зазначенням SMART цілей розвитку IПК, очікуваних 
результатів (що саме буде свідчити про досягнення навчальних цілей) і термінів їх досягнення, а також добирає форми й методи вдосконалення зазначеного в цілях уміння, враховуючи індивідуальний стиль навчання та рівень володіння мовою.

Наприклад, мета розвитку ІПК - вдосконалення вміння виступати з презентаціями для просування товарів і послуг на міжнародному IT ринку. Очікувані результати:

1. вміти структурувати зміст виступу / презентації;

2. володіти відповідними експонентами мовленнєвих функцій, які використовуються у процесі виголошення виступу (привітання аудиторії, представлення себе і своєї компанії, оголошення теми, мети й актуальності доповіді, повідомлення структури презентації, акцентування уваги на основних тезах доповіді, наведення аргументів і прикладів з метою розлогішого розкриття головної ідеї, вміння описувати тенденції та коментувати візуальну інформацію, подану у вигляді графіків, таблиць тощо, підсумовування основних моментів доповіді; володіння відповідними стратегіями реагування на запитання аудиторії тощо);

3. володіти відповідними лексико-граматичними структурами IT сфери (відповідна термінологія для опису IT продукту / послуги, пояснення її / його переваг тощо);

4. вміти використовувати невербальні засоби комунікації в публічній промові (міміка, жести).

Добираючи форми й методи вдосконалення вищевказаного вміння, варто допомогти студенту / фахівцю скласти словник відповідних лексико-граматичних структур і мовленнєвих експонентів та запропонувати йому відтренувати їх на практиці. 3 цією метою студент / фахівець тренується виступати $з$ презентацією вдома, записавши свій виступ на відео, та знаходить на одному із сайтів для безкоштовного спілкування англійською мовою співрозмовника, якому буде цікаво поспілкуватись на тему IT товарів / послуг. У процесі підготовки до мовленнєвої діяльності студент / фахівець заповнює рефлексивний щоденник, у якому він вказує, що саме він виконав, чи було це, на його думку, результативно, яких успіхів досягнув та з якими труднощами стикнувся, а також продумати шляхи подолання зазначених труднощів. Крім цього, на цьому етапі студент / фахівець 3 певною періодичністю зустрічається з коучем для обговорення результатів підготовки до мовленнєвої діяльності. Обговорення відбувається у формі SWOT аналізу, а також з використанням таких методів навчання, як рольові ігри та симуляція.

На другому етапі відбувається безпосереднє здійснення мовленнєвої діяльності: студент / фахівець виступає із презентацією. Якщо є можливість, коуч спостерігає за виступом або ж студент / фахівець записує свій виступ на відео / аудіо. Такий відео- / аудіозапис дає змогу краще проаналізувати мовленнєву діяльність. Виступивши з презентацією, студент / фахівець здійснює рефлексію мовленнєвої діяльності, відповідаючи на запитання відкритого типу:

- Як, на Вашу думку, пройшла презентація (співбесіда, перемовини, нарада, телефонна розмова тощо)? Чому Ви дійшли такого висновку?

- Як ви думаєте, Вам вдалось досягнути мети мовленнєвої діяльності та цілей розвитку ІПК? Чому і на основі аналізу яких даних Ви дійшли такого висновку?

- Що було позитивного у Вашій мовленнєвій діяльності? 3 якими труднощами Ви стикнулись та що Ви змінили б, якщо б здійснювали цей вид мовленнєвої діяльності повторно?

- Беручи до уваги результати здійсненої Вами мовленнєвої діяльності, які Ваші наступні кроки?

- Ураховуючи результати рефлексії, яких висновків Ви дійшли та що нового відкрили для себе?

Останній етап - обговорення результатів мовленнєвої діяльності, який пропонуємо проводити у формі рефлексивного діалогу, складається з чотирьох частин. Перша частина - 
це вступне слово коуча, під час якого він задає тон бесіді, встановлює часові рамки та ознайомлює студента / фахівця 3 порядком проведення рефлексії. Друга частина це обговорення питань, на які студент / фахівець відповідав під час проведення саморефлексії. Наступна частина - це аналіз позитивних аспектів мовленнєвої діяльності, а також тих аспектів, які потребують покращення. Завершальна частина - продумування наступних кроків удосконалення мовленнєвої діяльності.

Висновки і перспективи подальших розвідок. Отже, мовний коучинг доцільно використовувати як одну з технологій навчання англійської мови професійного спрямування 3 метою розвитку ІПК студентів / фахівців з рівнем володіння англійською мовою щонайменше на рівні А2, відштовхуючись від їхніх реальних комунікативних потреб. Основний інструмент коучингу - постановка запитань відкритого типу, які спонукають студентів / фахівців до рефлексії мовленнєвої діяльності. Враховуючи психофізіологічні механізми мовлення й умови ефективного здійснення коучингово супроводу, вважаємо за доцільне проводити мовний коучинг у три етапи (визначення цілей розвитку ІПК та підготовка до мовленнєвої діяльності, здійснення мовленнєвої діяльності, обговорення ії результатів), залучаючи студентів / фахівців до циклу неперервного розвитку ІПК.

Перспективу подальших наукових розвідок вбачаємо в обгрунтуванні й розроблені мультимедійного комплексу навчально-методичних матеріалів для розвитку ІПК у процесі коучингового супроводу 3 дотриманням принципів гнучкості навчального матеріалу та адаптивності процесу навчання до індивідуальних потреб й можливостей студентів / фахівців.

\section{ЛIТЕРАТУРА}

Выготский, Л. С. (1999). Мышление и речь (Изд. 5, испр.). Москва: Лабиринт.

Єфімова, О. М., Жицька, С. А. (2017). Коучинг як складова особистісно-орієнтованого навчання у професійній підготовці студентів вищих навчальних закладів. Науковий огляд, 4(36). Відновлено 3: https://naukajournal.org/index.php/naukajournal/article/view/1185

Зимняя, И. А. (1991). Психология обучения иностранныли языкам в школе. Москва: Просвещение. Коробко, О. М. (2009). Роль психологічного механізму випереджального відображення у процесі формування навичок говоріння іноземною мовою (на прикладі англійської мови). Наукові записки Національного університету “Острозька академія”. Серія: Психологія і педагогіка, 12, 116-121.

Лозова,О. М. (2010). Психологічні аспекти засвоєння іноземної мови. (Навчально-методичний посібник). Київ: Київський національний лінгвістичний університет

Самохвалова, А. Г. (2012). Рефлексивные трудности ребенка в коммуникативной деятельности. Вестник КГУ имени Н.А. Некрасова, 18, 198-200.

Шапар, В. Б. (2005). Сучасний тлумачний психологічний словник. Харків: Прапор.

Costa, A., Garmston, R. J. (2002). Cognitive coaching (2nd ed.). Norwood, MA: Christopher-Gordon. Knight, J. (2009). Coaching: Approaches and perspectives. ThousandOaks, CA: CorwinPress.

Knight, J. (2007). Five Key Points to Building a Coaching Program. Journal of Staff Development, 28 (1), 26-31.

Lord, P. Atkinson, M., Mitchell, H. (2008). Mentoring and Coaching for Professionals: a Study of the Research Evidence. Research Repor. TDA: London.

Paling, R. M. (2014). The Differences between Language Teaching and Language Coaching. International Multidisciplinary Research Journal, 2 (5), 13-19.

Rother, M. (2011). The Five Coaching Kata Questions. Retrieved from https://www.slideshare.net/ mike734/the-five-questions

Toll, C. A. (2005). The literacy coach's survival guide: Essential questions and practical answers. Newark, DE: International Reading Association. 
Zeppos, D. (2014). Profiling Neurolanguage Coaches World wide - A Case Study. World Journal of Education, 4 (6), 26-41.

\section{REFERENCES}

Vyhotskyj, L. S. (1999). Myshlenye i rech( Yzd. 5, ispr.). Moskva: Labyrynt.

Yefimova, O. M., Zhytska, S. A. (2017). Kouchynh iak skladova osobystisno-oriientovanoho navchannia u profesijnij pidhotovtsi studentiv vyschykh navchal'nykh zakladiv. Naukovyj ohliad, 4(36).

Vidnovleno z: https://naukajournal.org/index.php/naukajournal/article/view/1185

Zymniaia, Y. A. (1991). Psykholohyia obuchenyia inostrannym iazykam v shkole. Moskva: Prosveschenye.

Korobko, O. M. (2009). Rol psykholohichnoho mekhanizmu vyperedzhalnoho vidobrazhennia u protsesi formuvannia navychok hovorinnia inozemnoiu movoiu (na prykladi anhlijs'koi movy). Naukovi zapysky Natsional'noho universytetu "Ostroz'ka akademiia". Seriia: Psykholohiia i pedahohika, 12, 116-121.

Lozova, O. M. (2010). Psykholohichni aspekty zasvoiennia inozemnoi movy. (Navchal'no-metodychnyj posibnyk). Kyiv: Kyivskyi natsionalnyi linhvistychnyi universytet

Samokhvalova, A. H. (2012). Refleksyvnye trudnosty rebenka v kommunykatyvnoj deiatel'nosty Vestnyk KHU ymeny N.A. Nekrasova, Tom 18, 198-200.

Shapar, V. B. (2005). Suchasnyj tlumachnyj psykholohichnyj slovnyk. Kharkiv: Prapor.

Costa, A.,Garmston, R. J. (2002). Cognitive coaching (2nd ed.). Norwood, MA: Christopher-Gordon.

Knight, J. (2009). Coaching: Approaches and perspectives. Thousand Oaks, CA: CorwinPress.

Knight, J. (2007). Five Key Points to Building a Coaching Program. Journal of Staff Development, 28 (1), 26-31.

Lord, P. Atkinson, M., Mitchell, H. (2008). Mentoring and Coaching for Professionals: a Study of the Research Evidence. Research Repor. TDA : London.

Paling, R. M. (2014). The Differences between Language Teaching and Language Coaching. International Multidisciplinary Research Journal ,2 (5), 13 - 19.

Rother, M. (2011). The Five Coaching Kata Questions. Retrieved from https://www.slideshare.net/ mike734/the-five-questions

Toll, C. A. (2005). The literacy coach's survival guide: Essential questions and practical answers. Newark, DE: InternationalReadingAssociation.

Zeppos, D. (2014). Profiling Neurolanguage Coaches Worldwide - A Case Study. World Journal of Education, 4 (6), 26 - 41. 